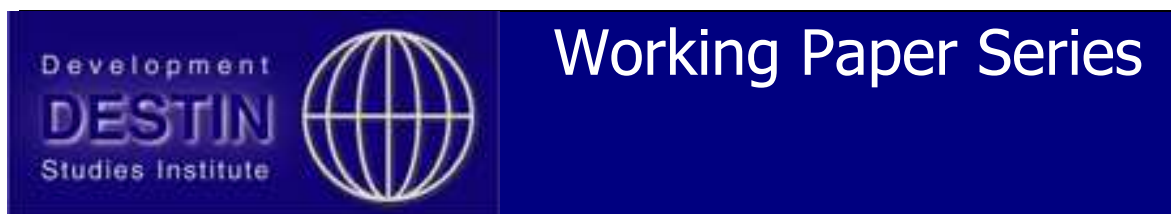

ISSN $1470-2320$

2011

No.122-11

\title{
Explaining African Ethnic Diversity
}

\section{Elliott Green}

Published: March 2011

Development Studies Institute

London School of Economics and Political Science

Houghton Street

Tel: $+44(020) 79557425 / 6252$

London

Fax: +44 (020) 7955-6844

WC2A 2AE UK

Email: $\underline{\text { d.daley@Ise.ac.uk }}$

Web site: www.Ise.ac.uk/depts/destin 


\title{
Explaining African Ethnic Diversity
}

\author{
ELLIOTT GREEN \\ Department of International Development \\ London School of Economics \\ Houghton Street \\ London WC2A $2 A E$ \\ e.d.green@1se.ac.uk
}

\begin{abstract}
:
The costs and consequences of ethnic diversity in Africa have been widely noted. However, despite Africa's high level of ethnic diversity and its large internal variation, the sources of this diversity remain unexplained. Here we show that ethnic diversity in Africa is a result of its tropical location, the pre-colonial slave trade, the colonial creation of large states and low levels of urbanization. The effect of these variables are robust to various controls and specifications. We also show that, once pre-colonial slavery is introduced, an African dummy variable becomes insignificant in regressions containing a world-wide sample of countries.
\end{abstract}




\section{INTRODUCTION}

In recent years Sub-Saharan Africa's ethnic diversity has become almost synonymous for the continent's economic and political problems. Scholars have argued that ethnic diversity has been responsible for Africa's low economic growth (Easterly and Levine 1997; Posner 2004a), political instability and conflict (Buhaug 2006; Easterly 2001), high inequality (Barr and Oduro 2002; Milanovic 2003) and low provision of public goods (Kimenyi 2006; Miguel and Gugerty 2005). ${ }^{1}$ What remains unexplained, however, are the origins of Africa's ethnic diversity.

In particular what makes Africa particularly interesting in this regard is both its unusually high levels and large internal variation in ethnic diversity. As regards the former, previous attempts to explain global ethnic diversity still find an Africa dummy variable to be statistically significant (Ahlerup and Olsson 2009; Michalopoulos 2008). As regards the latter, Africa's standard deviation in the number of ethnic groups per country is more than $35 \%$ higher than any other region according to one recent dataset on ethnic diversity (Fearon 2003, 204). ${ }^{2}$ Moreover, as seen in Table 1, another recent dataset from Alesina, Devleeshauwer, Easterly, Kurlat, and Wacziarg (2003) shows that the standard deviation in ethnic diversity per country as measured by the EthnoLinguistic Fractionalization (ELF) index is similarly largest in Africa, ${ }^{3}$ which also contains the countries with the smallest and largest measures of ethnic diversity in the world. Indeed, in a continent with high levels of diversity in such countries as Liberia and Uganda it is striking to find largely homogenous countries like Burundi and Comoros.

\section{[Insert Table 1 here]}

\footnotetext{
${ }^{1}$ Here and henceforth we refer to Sub-Saharan Africa merely as Africa.

${ }^{2}$ The next highest region is Asia.

${ }^{3}$ The ELF index is computed by summing the squares of all ethnic groups larger than $1 \%$ of the population and subtracting them from 1 .
} 
In this paper we therefore probe the origins of African ethnic diversity. We show that ethnic diversity within Africa is a result of its low latitudes, the pre-colonial slave trade, the creation of large colonial states and low levels of urbanization. More specifically, we demonstrate that a variable capturing the number of slaves exported per country between 1400 and 1900 eliminates the statistical significance of an Africa dummy variable in regressions containing a world-wide sample of countries. We also show that low population densities led colonialists to create large states, thereby leading to higher levels of ethnic diversity within Africa. Finally, we use a lagged measure of urbanization to demonstrate that urbanization is correlated with ethnic homogenization over time. The paper thus suggests that African ethnic diversity has pre-colonial, colonial and post-colonial roots and is continuing to change.

The paper is organized as follows. First, we examine a variety of theories for the origins of African ethnic diversity. Second, we test these theories in a series of multivariate regressions, finding that low latitude, the slave trade and state size are consistently associated with higher levels of diversity. Third, we perform additional tests on change in ethnic identity over time, confirming the role of urbanization in the late $20^{\text {th }}$ century. Finally we conclude with wider thoughts on African ethnic diversity.

\section{AFriCAN ETHNIC Diversity IN HistoriCAL PERSPECTIVE}

The vast majority of political economy work on Africa takes ethnicity as fixed and thus uses it as an independent variable rather than a dependent variable. ${ }^{4}$ This phenomenon has continued to occur despite the fact that anthropologists began to move away from a "primordial" understanding of ethnicity towards a more "constructivist" point of view in the late 1960s (Barth 1969; Cohen 1969). Indeed, of late political scientists and sociologists have continued to emphasize the

\footnotetext{
${ }^{4}$ See for instance Easterly and Levine (1997) and Miguel and Gugerty (2005), among many others.
} 
dynamism of ethnicity (Brubaker 2004; Chandra 2006), although it is too early to say whether these scholars have made a major impact on the field.

One strong conclusion that has come out of the constructivist literature is that modern processes of economic and political development have profoundly shaped ethnic identities. Gellner (2006 [1983]), for instance, proposed that industrialization can have a strong impact on the formation of cross-ethnic national identities, while the colonial state has been acknowledged to have had a major impact on shaping modern ethnic identities in Africa (Laitin 1994; Posner 2003). We thus focus our attention here on a variety of potential causes of African ethnic diversity, first beginning with pre-colonial and colonial origins in the rest of section 2 before moving onto postcolonial sources in section 3.

\subsection{Pre-Colonial and Colonial Origins}

There are several already existing hypotheses about the origins of Africa's pre-colonial ethnic diversity. Several of these are geographic in nature: for instance, many scholars have suggested that latitude and/or temperature has an inverse relationship with ethnic diversity, in that warm tropical environments are ideal for growing food and thereby create few incentives for inhabitants to migrate elsewhere or trade extensively with other human populations. This isolation thus spurs the creation of new ethnic groups in very much the same way as Darwin had proposed for finch species in the Galapagos islands (Ahlerup and Olsson 2009; Cashdan 2001; Collard and Foley 2002; Nichols 1992; Sutherland 2003). Other researchers have found a significant positive correlation between elevation and ethnic diversity (Nichols 1992; Sutherland 2003), which presumably works along the same mechanisms of encouraging isolation among human populations.

An alternative hypothesis for the pre-colonial era is the slave trade: as argued by Nunn (2008), the slave trade may have weakened ties between Africans and thereby inhibited the development of broader ethnic identities. Empirically there is a good deal of evidence supporting a 
relationship between slavery and ethnic diversity: Nunn (2008, 164), for instance, shows a significant and strong correlation between slave exports per area and contemporary ethnic fractionalization. The names of many African ethnic groups also suggest a link, such as the Dioula of West Africa, whose name comes from the Manding word gyo-la, or "the land of the slaves captured through warfare," while the name of their neighbours the Gio possibly comes from the Bassa phrase gii-o, or "slave people" (Holsoe and Lauer 1976, 141-142). Moreover, this evidence is not limited to West Africa: data from 1856 on freed slaves in what is now north-west Mozambique lists at least 21 different ethnic backgrounds (Isaacman 1972, 447), while the current Bantu ethnic minority in southern Somalia originated as slaves from southern Africa who were shipped along the East African coast in the $19^{\text {th }}$ century by Zanzibari traders (Webersik 2004, 525526).

Moving closer to the present, scholars have long argued that the colonial period had a profound effect on ethnicity in Africa, for a variety of reasons. In particular the literature suggests that colonialists directly promoted ethnic diversity through "divide and rule" tactics (Berman 1998; Blanton, Mason, and Athow 2001) and indirectly by providing "tribal" chiefs and missionaries with the incentives to promote ethnic differences (Laitin 1994). Scholarship on the colonial period has also repeatedly emphasized the way colonies were governed according to cost-saving methods. Indeed, at the time of its colonization Africa was relatively peripheral to European economic interests (Young 1994, 84-85), and the principle of colonial self-sufficiency meant that colonies had to pay for themselves, no matter how oddly shaped or small they were.

The consequences of colonial cost-saving on African ethnic diversity were threefold. First, European efforts at creating economies of scale and minimizing bureaucratic costs led to the creation of large states (Green 2012). For instance, the average British district commissioner was responsible for an area the size of Wales (Herbst 2000, 78), while French colonial administrators created unusually large colonies in the more under-populated areas of Central and West Africa. The result has been that the median former colony in Africa is $37 \%$ and $74 \%$ larger than the median 
former colony in Latin America and the Caribbean or Asia, respectively (Green 2012). ${ }^{5}$ When we recall that ethnic groups in Africa are different from caste groups in India or racial groups in the US in the way they tend to be regionally concentrated, it is thus no surprise to find that smaller African states like Burundi, Djibouti and Lesotho have lower levels of ethnic diversity than Chad, the DRC or Tanzania. ${ }^{6}$

A second consequence of colonial cost-saving was the drawing of arbitrary colonial borders. More specifically, due to the costs involved in drawing accurate borders that reflected local political economies, Europeans inadvertently "split up ethnic groups and exacerbated pre-existing high levels of ethnic and linguistic diversity" when dividing up the continent (Easterly and Levine 1997, 1213). In particular Englebert, Tarango, and Carter $(2002,1096)$ have noted that some $44 \%$ of colonial borders were straight lines, leading to as many as 177 ethnic groups split across two and sometimes three colonial borders; when added together these partitioned ethnic groups represented $43 \%$ of the average African state's population. Indeed, the supposed arbitrariness of these borders has led some social scientists like Miguel (2004) and Posner (2004b) to use them as "natural" experiments inasmuch as they were supposedly drawn exogenous to pre-existing local political conditions. ${ }^{7}$

A third consequence of colonial cost-saving was the creation of supposedly homogenous rural "tribal" areas with their own "tribal" chiefs as "decentralized despots" (Mamdani 1996). Labelled as "indirect rule," this policy led in areas to the creation of new ethnic identities as colonialists split up Africans into separate tribal areas with their own tribal chiefdoms, thereby

\footnotetext{
${ }^{5}$ These comparisons exclude island states; when they are included the differences are even more stark.

${ }^{6}$ It is thus also not surprising that Michalopoulos (2008) finds no correlation between state size and ethnic diversity on a global scale, as also seen below.

${ }^{7}$ However, Green (2012) shows that, far from arbitrary, the artificial shape of many colonial borders were instead a result of low pre-colonial population densities.
} 
encouraging separation and ethnic difference. Moreover, the way in which colonial rule restricted both migration between tribal areas and property rights to "natives" from each area only helped to encourage isolation and further fractionalization.

\subsection{Empirical Analysis}

Our goal is thus to regress ethnic diversity on these aforementioned variables. As already noted there exists two recently compiled datasets on global ethnic diversity, namely Alesina et al. (2003) and Fearon (2003). What makes these dataset different from previous codings of ethnic diversity is its focus on ethnic rather than ethnolinguistic diversity, whereby groups in Rwanda and Somalia who speak the same language but are ethnically distinct are coded as such. Thus we deliberately do not employ other datasets that explicitly use language as a proxy for ethnicity such as Roeder (2001) and Taylor and Hudson (1972). ${ }^{8}$ We utilize both of these new datasets here inasmuch as they both have advantages and disadvantages: in particular, Alesina et al. (2003) has a wider coverage of countries but is slightly less accurate in certain cases than Fearon (2003), such as with Tanzania. ${ }^{9}$

To summarize our hypotheses, we have listed seven historic variables here which are hypothesized to have effects on ethnic diversity in Africa: for the pre-colonial period we have

${ }^{8}$ Another recent dataset was compiled by Annett (2001); as it is based on older sources and contains fewer observations than Alesina et al. (2003) and Fearon (2003) we do not use it here. Nonetheless all of the results presented here are robust to the use of Annett (2001)'s data as well.

${ }^{9}$ More specifically, countries such as Tanzania and Togo do not have their ethnic identity labels listed in the dataset, a problem which does not occur with Fearon (2003)'s data. As a possible result of these miscoding problems, Alesina et al. (2003) list Tanzania's ethnic diversity score as only 0.735, far below both Fearon (2003)'s score of 0.95 and the 1967 Tanzanian census's score of 0.96 (Government of Tanzania 1969). (The 1967 census was the last to measure ethnicity in Tanzania.) 
elevation, latitude, temperature and slave exports and for the colonial period we listed state size, artificial borders and indirect rule. Several variables present no problems in measurement, with uncontroversial data available for elevation, latitude, temperature and state size. ${ }^{10}$ Other data, however, present certain problems. Nunn (2008), for instance, uses current ethnic group identities to code historical slave exports, which he then claims led to the creation of modern ethnic groups, a problem which has been already criticized elsewhere (Austin 2008). The other problem with this data is that it measures slaves per area that were exported from Africa, thereby excluding the majority of African slaves who never left the continent (Lovejoy 2000). However, we use his data here as it is so far the only such cross-national data on slave exports.

Artificial borders could be estimated according to Englebert et al. (2002)'s estimates on the number of straight and non-straight borders in Africa. However, more recently and finally, we utilize a new "fractal" measure of artificial borders by Alesina, Easterly, and Matuszeski (2011) which captures the degree to which a country's land borders are one or two dimensional. Thus African countries range from the straight-line borders of Somalia (fractal $=0.003)$ and Equatorial Guinea (0.007) to the curved and jagged borders of Sierra Leone (0.055) and Rwanda (0.072).

Finally, measuring indirect rule is also problematic since the sole available measure is one created by Lange (2004) for British colonies, leaving us with only 14 observations and a nonrepresentative sample. ${ }^{11}$ Another alternative is to use colonial identity as a proxy for indirect rule, inasmuch as there is some evidence that the British were more forthright in using indirect rule than the French in their African colonies (Blanton et al. 2001; Grier 1999). We thus introduce colonial dummies for the three main colonial powers of France, Portugal and the UK.

\footnotetext{
$\overline{{ }^{10} \text { For all data sources see Appendix } 1 .}$

${ }^{11}$ Interestingly, regressing both ELF measures on indirect rule results in a negative relationship (which is not statistically significant using Fearon's data but significant at $\mathrm{p}=0.081$ with Alesina's data), suggesting that, if anything, indirect rule promoted ethnic homogenization rather than fractionalization.
} 
We begin our analysis by testing various historical variables against each other. Columns 13 employ Alesina et al. (2003) as the dependent variable while columns 4-6 employ Fearon (2003). Inasmuch as elevation and temperature are highly correlated $(r=-0.72)$ with each other for obvious reasons, we include them in separate regressions. We also report the results with the fractal variable separately in columns 3 and 6 as Alesina et al. (2011) do not compute their data for every African country.

Nonetheless, as reported in Table 2, we find a series of consistent results. First, absolute latitude is correlated with ethnic diversity across all six specifications while elevation, temperature and the colonial dummy variables are never significant. Second, slave exports are always positively and significantly correlated with ethnic diversity, with a consistent coefficient around 0.02 , as is state size with a coefficient between 0.04 and 0.05 . Moreover, in all six regressions we explain a majority of the variation in ethnic diversity across Africa.

[Insert Table 2 here]

To examine whether these variables explain the Africa dummy variable we can thus regress Alesina et al. (2003) and Fearon (2003) on a series of variables on a global scale. However, Nunn (2008)'s data on slavery was only calculated for Sub-Saharan and North Africa. We can supplement this data by examining non-African countries where evidence exists that they exported slaves in commercial exchanges between 1400 and $1900 .^{12}$ While by no means as well documented as the Atlantic slave trade, recent scholarship has begun to estimate the number of slaves involved and their origin in the early modern Indian Ocean, Central Asian and Crimean slave trades. As in

\footnotetext{
${ }^{12} \mathrm{We}$ do not include data on slaves captured through warfare as it does not represent any commercial exchange, as for examples with Indian soldiers enslaved in 1647 after a failed siege in Afghanistan (Levi 2002, 280).
} 
Nunn (2008) we normalize the export figures by take the natural log of the total number of exports divided by the size of the country (and multiplied by 1000).

Our new data, summarized in Appendix 2, shows that Africa was by no means the only part of the world to export significant numbers of slaves in the early modern period. For instance, evidence suggests that the slave trade in the Indian Ocean not only exported slaves from east Africa but also from the Coromandel coast in south India and the Arakan/Bengal coast in what is now Bangladesh and Myanmar (Carter 2006; Vink 2003). Moreover, there is evidence of Portuguese slave traders exporting slaves from India, Indonesia and Malaysia to Manila in the late $16^{\text {th }}$ and early $17^{\text {th }}$ centuries (Seijas 2008, 22-23), while Warren (2007, xxxv) estimates that around 300,000 slaves from Indonesia and the Philippines were exported to the Sulu Sultanate (in what is now south-west Philippines) between 1768 and 1878.

As for the Central Asian slave trade, the expansion of the Mughal Empire in the $16^{\text {th }}$ and $17^{\text {th }}$ centuries resulted in "the enslavement and exportation of hundreds of thousands of individuals" from what is now India and Pakistan (Levi 2002, 283-284), which we estimate here as around 300,000 people. Given a ratio of $2: 1$ of Indo-Pakistani slaves to Afghan slaves in late $16^{\text {th }}$-century Samarkand (Levi 2002, 284), we also estimate that roughly 150,000 Afghans were subjected to the Central Asian slave trade. ${ }^{13}$ Finally, an estimate that half of the population of Khanata of Khiva was comprised of Persian slaves in 1851 suggests that Iran exported a minimum of 350,000 slaves during this period (Hopkins 2008, 645). To compare these figures with Nunn (2008)'s African data suggests that slave exports from Afghanistan were roughly proportional to the number of exports from Congo-Brazzaville while Iran was more comparable to Madagascar and India/Pakistan to Ethiopia.

But perhaps the most striking numbers come from Kizilov (2007, p. 7), who suggests that there were roughly 2 million slaves exported from nine countries in Eastern Europe through the

\footnotetext{
${ }^{13}$ The results below are robust to a variety of higher and lower estimates for Afghanistan, India and Pakistan.
} 
Crimean Slave trade between 1500 and 1700. Indeed, one source discusses the negative political and demographic effects of slavery in early modern Georgia in much the same way as it is often discussed Africa:

The constant feudal warfare and the miserable life of the serfs on the individual estates served the interests of the slave traders so well that the population of the entire region was greatly reduced by the eighteenth century to the benefit of the rival Safavid and Ottoman states (Kortepeter 1966, 105).

With this new data we can thus estimate the effect of slavery on contemporary measures of ethnic diversity on a global scale and observe whether it has any effect on the Africa dummy variable. ${ }^{14}$ Table 3 presents our results, again using both datasets as dependent variables. We first start out in columns 1 and 3 by regressing ELF on a set of variables already demonstrated by Ahlerup and Olsson (2009) and Michalopoulos (2008) as correlating with global ethnic diversity, namely elevation, latitude, state size and dummies for British, French and Spanish colonial rule. We include an African dummy as well as a Europe dummy inasmuch as these are the only two continent dummy variables that are significantly correlated with ELF in univariate regressions. In both regressions both latitude and the Africa dummy are highly significant in the expected directions.

[Insert Table 3 here]

In columns 2 and 4, however, we introduce the updated slavery variable, which is not only highly statistically significant but also entirely removes the significance of the Africa dummy.

\footnotetext{
${ }^{14}$ This exercise is thus similar to Englebert (2000)'s efforts in eliminating the statistical significance of the Africa dummy in a series of growth regressions. Interestingly Englebert (2000)'s newly created "legit" variable does not eliminate the effect of the Africa dummy when regressing ethnic diversity instead of growth.
} 
Interestingly the slavery variable has no significant effect on any other variable other than to slightly weaken the effect of latitude and increase the effect of elevation (albeit still at nonsignificant levels); the Europe dummy also increases its statistical significance slightly. Finally, it is important to note that the slavery variable produces a higher $\mathrm{R}^{2}$ as well in both regressions; indeed, in univariate regressions the slavery variable explains $27 \%$ of the variation in ELF in the Fearon dataset and $29 \%$ in the Alesina dataset despite the fact that our data only records 61 countries as having exporting any slaves at all.

\section{CONTEMPORARY AFRICAN ETHNIC DIVERSITY}

\subsection{Post-Colonial Origins}

So far we have examined the potential effects of historical variables on African ethnic diversity. Here we turn towards more contemporary variables, in particular suggestions from many scholars that modern political and socio-economic development can alter ethnic diversity. For instance, Alesina and Spolaore (2003) have suggested that ethnic heterogeneity leads to poorer public goods provision due to diverse preferences, and that as a result citizens from ethnically heterogeneous states have the incentive to secede and create new, more ethnically homogenous states. They claim that these incentives would be enhanced as countries democratize and thus give their citizens greater latitude to choose their own future. Yet there is very little evidence supporting this theory in post-colonial Africa, where there has been a remarkable lack of secessionist movements even after democratization swept the continent in the 1990s (Englebert 2009).

There is more evidence behind two other processes in the post-colonial period, namely nation-building and urbanization. As regards the former, modernization theorists like Gellner (2006 [1983]) argued that political and economic development would produce more homogenous societies, both because ethnic divisions of labour would lead to secession and the creation of more 
homogenous states and because industrialization required states to create largely homogenous workforces which could easily communicate with each other. Indeed, most African governments in the 1960s and 1970s attempted to create common national identities that transcended ethnicity, following Mozambiquean President Samora Machel's dictum that, "for the nation to live, the tribe must die" (Mamdani 1996, 135). Thus Botswana's success in promoting both economic growth and political stability has led some authors like Acemoglu, Johnson, and Robinson (2003, 106) to suggest that its unusually high ethnic homogeneity is "more an outcome of Botswana's political institutions than an independent cause."

A second theorized explanation for ethnic change is urbanization. Social theorists from Marx and Engels to Gellner (2006 [1983]) have invoked urbanization as a key variable in the transition from old multi-ethnic agrarian societies to modern nation-states, while historians like Weber (1976) have shown how urbanization spread nationalist ideology and homogenization in France and other western countries in the $19^{\text {th }}$ and $20^{\text {th }}$ centuries. In particular urbanization has been seen as both the mechanism by which people from different but related ethnic groups come in contact with each other, realize their commonalities and form new and broader ethnic identities, and the means by which the state can enforce nationalist ideology through education and propaganda. Rural citizens, on the other hand, remain isolated from each other physically and socially, and modern nation-states have often had difficulties reaching out to their rural peripheries. Within Africa perhaps the best example of the effects of urbanization on ethnic diversity phenomenon is Botswana, which had a $7.1 \%$ annual rate of urbanization between 1960 and 2000, or the highest of any country in the world. ${ }^{15}$ The result of such a large-scale shift was the creation of neutral ethnic spaces which "provided an enabling context for minorities to join and partially 'assimilate' to national life" (Solway 2004, 132).

${ }^{15}$ The only other country which had an urbanization rate above $5 \%$ over this period was Mozambique (5.3\%) (United Nations 2008). 
In Africa the relative lack of urbanization could be one reason behind the continent's high ethnic diversity. Indeed, colonial rulers deliberately suppressed urbanization until the midtwentieth century, partially due to the need to utilize labor in rural areas but also because they were worried about the existence of an urban "detribalized" proletariat as a fertile recruiting tool for nationalist anti-colonial movements (Mamdani 1996, 102). Many of these policies persisted into the post-colonial era, as most African governments solved urban housing shortages by taking up "systematic round-ups and expulsions of urban dwellers living in self-constructed shacks" (Freund 2007, 148). Governments often targeted the urban unemployed or underemployed, who were then redeployed to rural areas in a direct continuation of colonial policy (albeit with "greater zeal") (Brennan 2006, 403). The result has been that, as demonstrated in Table 4, Africa remains the continent with the lowest level of urbanization, and is projected to become a majority urban region only after 2030 .

\section{[Insert Table 4 here]}

Yet, despite state efforts to suppress urbanization, the dual effects of colonial pacification and economic development programs have encouraged urbanization indirectly via high population growth, local land scarcities and out-migration from tribal areas. While some of these migrants moved to rural areas, many of them moved to cities, where they formed new ethnic identities. Indeed, as noted by Freund (2007, 90-91) and Wallerstein (1960, 133), Africans have often assimilated into larger ethnic groups in order to find security and prestige in the difficult urban environment. The Ibo of Nigeria, the Jola of Senegal, Duala of Cameroon and Bangala of the DRC can thus be seen as classic examples of previously different ethnic groups amalgamating into larger ethnic identities as urban migrants found commonalties among each other and transferred these new identities back to their rural brethren as well (Eckert 1999; Nugent 2008; Young 1976). 


\subsection{Empirical Analysis}

In order to see if nation-building and urbanization have had any effect in promoting ethnic homogenization within Africa we could regress ethnic diversity onto a variety of variables as in Table 2, but any correlation between the post-colonial variables and ethnic diversity would not, of course, tell us anything about causality. Moreover, inasmuch as different countries measure urbanization according to vastly different definitions any such static correlation across countries is bound to be inaccurate. ${ }^{16}$ Thus regressing change over time in levels of ethnic diversity on changes in nation-building and urbanization in long-difference model would allow us better insight into causal effects, and would also allow us to control for different definitions for urbanization and other variables like international migration. Theoretically one way to do this would be to use measures of ethnic diversity from different country census reports; yet this exercise is not feasible here as most African countries no longer ask questions about ethnicity on their censuses in large part because of the controversies surrounding ethnic headcounts (Morning 2008). There is, however, one extant source of changes in ethnic fractionalization over time, namely Roeder (2001)'s data on ethnic diversity in 1961 and 1985 as drawn from Soviet ethnographic sources.

As regards the independent variables we can measure annual rates of urbanization between 1950 and 1975 in order to allow for a 10-year lag. ${ }^{17}$ We can proxy for the role of nation-building in several ways. We proxy for economic nation-building through the net change in the percentage of citizens recorded as illiterate between 1950 and 1975, economic growth per capita between 1960

\footnotetext{
${ }^{16}$ Current thresholds for the classification of urban areas in Africa range from agglomerations of 1500 people in Equatorial Guinea to 10,000 in Senegal. Changes in definitions of urbanization do take place over time within countries but these changes are still dwarfed by the cross-country differences.

${ }^{17}$ We cannot create more than a 10-year lag as the UN data on urbanization only goes back to 1950. The results do not differ if we instead use a 5-year lag.
} 
and 1985 and annual growth in agricultural productivity between 1961 and 1985 . We can also proxy for political nation building by measuring the cumulative change in each country's Polity IV measure between 1960 and 1985. (Lagging the data for economic growth, agricultural productivity or Polity IV does not leave us with enough observations.)

We present our results in Table 5. In column 1 we regress change in ELF on urbanization between 1950 and 1975 while controlling for the initial 1961 ethnic diversity scores from Roeder (2001) to account for a convergence effect. In column 2 we add GDP/capita growth and change in Polity IV between 1960 and 1985. In column 3 we control for annual change in fertility and mortality alongside net migration inasmuch as changes in the population composition should have an effect on a given society's ethnic demographics. Finally, in column 4 we control for changes in illiteracy and agricultural productivity, both because the two variables are measures of nationbuilding but also because it is argued elsewhere that they should correlate with urbanization (Dyson 2001; Yuki 2007).

[Insert Table 5 here]

The results are clear: in all four regressions the coefficient for urbanization is both statistically significant and consistently located between -0.84 and -1.15 , suggesting that higher rates of urbanization is correlated with ethnic homogenization within Africa. None of the other variables are statistically significant at the 5\% level except migration, whose negative value surprisingly suggests that immigration is correlated with lowered levels of ethnic diversity rather than the higher levels experienced among highly urbanized countries elsewhere (Green 2011).

We can also estimate the effects of urbanization on ethnic diversity over time. More specifically, if we use the mean coefficient of -0.945 from Table 5, the urbanization rate of $2.7 \%$ between 1950 and 1975 for the whole of Africa should have lowered the continent's mean level of ethnic diversity by 0.026 between 1961 and 1985 . While this amount may seem small - at this rate 
it would take Africa over two hundred years to drop from its current mean level of 0.71 to the current global mean of 0.48 as measured by Fearon (2003), and even longer if urbanization rates continue to drop as predicted - this result nonetheless adds further evidence that African ethnic diversity is indeed dynamic and endogenous to social phenomena.

\section{INTERPRETATION}

Our results thus suggest that latitude, slave exports, state size and urbanization play a strong causal role in African ethnic diversity, and that other hypothesized causes have little to no significant effect. Indeed, while at first the negative results for the other hypothesized variables are counterintuitive, a closer look at the evidence suggests otherwise. As regards the pre-colonial variables, previous scholars have found contradictory evidence: Nettle (1996), for instance, finds no relationship between diversity and elevation in West Africa, while many of studies mentioned above only examine bivariate correlations and therefore fail to check if any variables lose significance and/or coefficient size in multivariate regressions. The significance of latitude here, however, merely confirms previous findings from Ahlerup and Olsson (2009) and Michalopoulos (2008).

As for the colonial period, there is a good amount of equivocal evidence about the impact of both arbitrary borders and indirect rule on ethnic diversity. For instance, despite their lack of detailed ethnographic knowledge European colonialists often tried to avoid splitting indigenous states between colonies when they could: the Angola/Zambia, Benin/Nigeria, Ghana/Burkina Faso, Niger/Nigeria, and Rwanda/Tanganyika borders, among others, were all drawn to ensure that precolonial African states were not partitioned. Indeed, the British Prime Minster Lord Salisbury pushed for the Ndian river to be demarcated as the border between Nigeria and Kamerun in 1887 as it marked "a distinct ethnographic frontier" between Bantu and non-Bantu peoples (Partridge and Gillard 1995, 251). After the partition of the German colonial empire in 1919 the then British 
Colonial Secretary was similarly concerned about the initial French/British border in the Cameroons as it "cut across tribal and administrative divisions," and was pleased at the addition of the British Cameroons and Togoland to the Empire as it brought "completely within our borders native Tribes which have hitherto been partly within British territory and partly outside it" (Louis 1966, 885-886). Finally, there is evidence as well of European powers allowing for the transfer of populations caught on the wrong side of the borders between Gambia and Senegal, the Belgian Congo and Uganda, and Kenya and Italian Somaliland in the early colonial period (Griffiths 1986; Trouval 1966).

There is also evidence that European "tribal" policies did not always increase pre-existing ethnic diversity. In many places such as central Uganda colonial policies had little effect on ethnic identities due to the strength of pre-colonial attachments (Green 2008). In other areas ethnic groups that were too small to be formed into individual chiefdoms or kingdoms were consolidated into larger groupings and given chiefs with "invented traditions" (Ranger 1983); in this way the Abaluhya of Kenya and Ndebele of Zimbabwe, among many others, were grouped together in a single district and eventually became single ethnic groups (Mamdani 1996, 81-82; Ndegwa 1997). It was not only the colonial state which promoted ethnic homogeneity through cost-saving: missionaries often "reduced Africa's innumerable dialects to fewer written languages" and thereby promoted ethnic homogeneity in large part due to budgetary constraints (Iliffe 2007, 239; Posner 2003).

In the post-colonial period most African states have done very little to promote nationbuilding and ethnic homogenization, focusing instead on superficial policies alongside the promotion of deep ethnic divisions that contributed to political instability and civil wars. While rare cases of political stability such as Tanzania have often seen a decreased salience of ethnic diversity, there is little concomitant evidence of ethnic homogenization (Miguel 2004), while a closer reading of post-colonial Botswana suggests that politicians there have actually done little to integrate ethnic minorities into a common national identity (Poteete 2009). Indeed, the most stringent example of 
nation-building in $20^{\text {th }}$-century Africa took place in Ethiopia, where efforts at promoting Amharic failed to contribute to ethnic homogenization but rather led to ethnic revolts against Emperor Hailie Selassie, the secession of Eritrea and the implementation of a system of ethnic federalism after 1993.

Finally, the results with urbanization correspond to the results from Robinson (2009)'s investigation into patterns of national identification in Africa. Using third-round Afrobarometer survey data from 21,937 respondents across 16 African countries, she found a strong correlation between urbanization and the likelihood of feeling more strongly attached to one's national identity than one's ethnic identity in a series of logistic regressions that included age, gender, education and wealth as controls. We carried out similar logistic regressions with fourth-round Afrobarometer data from 25,705 respondents across 19 countries and obtained the same robust effect of urbanization on nationalism with a variety of controls (results available from authors). These results thus provide further evidence of a causal effect of urbanization on ethnic homogenization.

\section{CONCLUSION}

In this paper we have shown that Africa's unusually high ethnic diversity has four sources, namely its tropical location, the early modern slave trade, the creation of large colonial states and low levels of urbanization. We demonstrated that the inclusion of a variable capturing the global early modern slave trade in regressions explaining global ethnic diversity makes an Africa dummy variable statistically insignificant. We also showed that these four variables are robust to various specifications and that a number of other variables such as indirect rule, artificial borders, economic growth and democratization are not robustly correlated with ethnic diversity.

As such this paper has two broad contributions to the literature on Africa and ethnic diversity. First, this paper suggests that Africa's ethnic diversity does not have mysterious origins. Africa's unusually high levels of ethnic diversity can be explained by its supply of slaves to the 
early modern slave trade, and its large standard deviation in ethnic diversity is the result of internal variation in latitudinal spread, state size and urbanization. The relationship between diversity and latitude confirms the results found by Ahlerup and Olsson (2009) and Michalopoulos (2008) on a global scale, and the significance of state size confirms the role of colonialists in creating ethnically diverse states in Africa, albeit not in the divide and rule strategy suggested above. Indeed, the results suggest that the unusual lack of secessionist movements in post-colonial Africa should thus not only be seen as partially responsible for the continent's lack of state formation and consolidation but also for its ethnic diversity (Englebert 2009; Herbst 2000). Finally, the ethnic diversity that pervaded rural society in other regions in the pre-modern era has persisted in Africa in part because of the continent's low levels of urbanization.

Second, it suggests that African ethnic diversity is not primordial or fixed and thus cannot continue to be used as an exogenous variable in analyses of African political economy. Further research in this area must continue to interrogate the primordialist assumptions that still plague the study of African ethnicity. Moreover, the results here suggest that measures to alleviate the negative effects of ethnic diversity could concentrate less on such suggestions as the creation of locally homogenous political units (Laitin 2007) and more on promoting urbanization as a means of ethnic homogenization. ${ }^{18}$

Additional research on this topic could focus on a number of important items. First, inasmuch as pre-colonial slave exports are significantly correlated with modern ethnic diversity, it is important to develop more accurate quantitative measures of pre-colonial slavery which do not use ethnicity for identification purposes and which better account for the internal slave trade within

${ }^{18}$ The United Nations recently documented in great detail the role of African governments in suppressing urbanization. For instance, in asking governments around the world in 2009 whether they wanted to raise, maintain or lower levels of rural-urban migration, $81 \%$ of African governments wanted to lower migration while $48 \%$ wanted to raise urban-rural migration. In both cases these were the highest percentages of any region in the world (United Nations 2010, 66, 70). 
Africa and Eurasia. Secondly, more substantial time-series data on ethnic change over time would improve our understanding of how political and economic phenomena affect ethnicity in Africa. Finally, similar analyses for other parts of the world would add to our knowledge on this subject. 
Bibliography

Acemoglu, Daron, Simon Johnson and James A. Robinson. 2003. An African Success Story: Botswana. In In Search of Prosperity: Analytical Narratives on Economic Growth, ed. Dani Rodrik, 80-119. Princeton, NJ: Princeton University Press.

Ahlerup, Pelle and Ola Olsson. 2009. The Roots of Ethnic Diversity. Department of Economics, Göteborg University.

Alesina, Alberto, Arnaud Devleeshauwer, William Easterly, Sergio Kurlat and Romain Wacziarg. 2003. Fractionalization. Journal of Economic Growth 8:155-194.

Alesina, Alberto, William Easterly and Janina Matuszeski. 2011. Artificial States. Journal of the European Economic Association 9:246-277.

Alesina, Alberto and Enrico Spolaore. 2003. The Size of Nations. Cambridge, MA: MIT Press.

Annett, Anthony. 2001. Social Fractionalization, Political Instability and the Size of Government. Washington DC: International Monetary Fund.

Austin, Gareth. 2008. The 'Reversal of Fortune' Thesis and the Compression of History: Perspectives from African and Comparative Economic History. Journal of International Development 20:996-1027.

Barr, Abigail and Abena Oduro. 2002. Ethnic Fractionalization in an African Labour Market. Journal of Development Economics 68:355-379.

Barth, Frederik, ed. 1969. Ethnic Groups and Boundaries: The Social Organization of Culture Difference. London: Allen and Unwin.

Berman, Bruce. 1998. Ethnicity, Patronage and the African State: The Politics of Uncivil Nationalism. African Affairs 97:305-341.

Blanton, Robert, T. David Mason and Brian Athow. 2001. Colonial Style and Post-Colonial Ethnic Conflict in Africa. Journal of Peace Research 38:473-492.

Brennan, James R. 2006. Blood Enemies: Exploitation and Urban Citizenship in the Nationalist Political Thought of Tanzania 1958-1975. Journal of African History 47:389-413. 
Brubaker, Rogers. 2004. Ethnicity Without Groups. Cambridge, MA: Harvard University Press.

Buhaug, Halvard. 2006. Relative Capability and Rebel Objective in Civil War. Journal of Peace Research 43:691-708.

Carter, Marina. 2006. Slavery and Unfree Labour in the Indian Ocean. History Compass 4:800-813.

Cashdan, Elizabeth. 2001. Ethnic Diversity and Its Environmental Determinants: Effects of Climate, Pathogens and Habitat Diversity. American Anthropologist 103:968-991.

Chandra, Kanchan. 2006. What is Ethnic Identity and Does it Matter? Annual Review of Political Science 9:397-424.

Cohen, Abner. 1969. Custom and Politics in Urban Africa: A Study of Hausa Migrants in Yoruba Towns. London: Routledge.

Collard, Ian F. and Robert A. Foley. 2002. Latitudinal Patterns and Environmental Determinants of Recent Human Cultural Diversity: Do Humans Follow Biogeographic Rules? Evolutionary Ecology Research 4:371-383.

Dyson, Tim. 2001. A Partial Theory of World Development: The Neglected Role of the Demographic Transition in the Shaping of Modern Society. International Journal of Population Geography 7:67-90.

Easterly, William R. 2001. Can Institutions Resolve Ethnic Conflict? Economic Development and Cultural Change 49:687-706.

Easterly, William R and Ross Levine. 1997. Africa's Growth Tragedy: Policies and Ethnic Divisions. Quarterly Journal of Economics 112:1203-1250.

Eckert, Andreas. 1999. African Rural Entrepreneurs and Labor in the Cameroon Littoral. Journal of African History 40:109-126.

Englebert, Pierre. 2000. Solving the Mystery of the AFRICA Dummy. World Development 28:1821-1835.

Englebert, Pierre. 2009. Africa: Unity, Sovereignty and Sorrow. Boulder, CO: Lynne Rienner. 
Englebert, Pierre, Stacy Tarango and Matthew Carter. 2002. Dismemberment and Suffocation: A Contribution to the Debate on African Boundaries. Comparative Political Studies 35:10931118.

Fearon, James D. 2003. Ethnic and Cultural Diversity by Country. Journal of Economic Growth 8:195-222.

Freund, Bill. 2007. The African City: A History. Cambridge: Cambridge University Press.

Gellner, Ernest. 2006 [1983]. Nations and Nationalism. Oxford: Blackwell.

Government of Tanzania. 1969. 1967 Population Census. Dar es Salaam: Government Printer.

Green, Elliott D. 2008. Understanding the Limits to Ethnic Change: Evidence from Uganda's Lost Counties. Perspectives on Politics 6:473-485.

Green, Elliott D. 2011. Endogenous Ethnicity. Department of International Development, London School of Economics.

Green, Elliott D. 2012. On the Size and Shape of African States. International Studies Quarterly 56:forthcoming.

Grier, Robin M. 1999. Colonial Legacies and Economic Growth. Public Choice 98:317-335.

Griffiths, Ieuan. 1986. The Scramble for Africa: Inherited Political Boundaries. Geographical Journal 152:204-216.

Herbst, Jeffrey I. 2000. States and Power in Africa: Comparative Lessons in Authority and Control. Princeton, N.J.: Princeton University Press.

Heston, Alan, Robert Summers and Bettina Aten. 2009. Penn World Table, Version 6.3, Center for International Comparisons of Production, Income and Prices at the University of Pennsylvania.

Holsoe, Svend E. and Joseph J. Lauer. 1976. Who are the Kran/Guere and the Gio/Yacouba? Ethnic Identification along the Liberia-Ivory Coast Border. African Studies Review 19:139-149.

Hopkins, B. D. 2008. Race, Sex and Slavery: 'Forced Labour' in Central Asia and Afghanistan in the Early 19th Century. Modern Asian Studies 42:629-671. 
Iliffe, John. 2007. Africans: The History of a Continent (2 ed.). Cambridge: Cambridge University Press.

Isaacman, Alan. 1972. The Origin, Formation and Early History of the Chikunda of South Central Africa. Journal of African History 13:443-461.

Kimenyi, Mwangi S. 2006. Ethnicity, Governance and the Provision of Public Goods. Journal of African Economies 15:62-99.

Kizilov, Mikail. 2007. Slave Trade in the Early Modern Crimea From the Perspective of Christian, Muslim, and Jewish Sources. Journal of Early Modern History 11:1-31.

Kortepeter, Carl M. 1966. Ottoman Imperial Policy and the Economy of the Black Sea Region in the Sixteenth Century. Journal of the American Oriental Society 86:86-113.

Laitin, David D. 1994. The Tower of Babel as a Coordination Game: Political Linguistics in Ghana. American Political Science Review 88:622-634.

Laitin, David D. 2007. Nations, States and Violence. Oxford: Oxford University Press.

Lange, Matthew. 2004. British Colonial Legacies and Political Development. World Development 32:905-922.

Levi, Scott C. 2002. Hindus Beyond the Hindu Kush: Indians in the Central Asian Slave Trade. Journal of the Royal Asiatic Society of Great Britain and Ireland 12:277-288.

Louis, William Roger. 1966. Great Britain and the African Peace Settlement of 1919. American Historical Review 71:875-892.

Lovejoy, Paul E. 2000. Transformations in Slavery: A History of Slavery in Africa (2 ed.). Cambridge: Cambridge University Press.

Mamdani, Mahmood. 1996. Citizen and Subject: Contemporary Africa and the Legacy of Late Colonialism. Princeton, N.J: Princeton University Press.

Michalopoulos, Stelios. 2008. The Origins of Ethnolinguistic Diversity: Theory and Evidence. Department of Economics, Tufts University. 
Miguel, Edward. 2004. Tribe or Nation? Nation Building and Public Goods in Kenya versus Tanzania. World Politics 56:327-362.

Miguel, Edward and Mary Kay Gugerty. 2005. Ethnic Diversity, Social Sanctions, and Public Goods in Kenya. Journal of Public Economics 89:2325-2368.

Milanovic, Branko. 2003. Is Inequality in Africa Really Different? Working Paper \#3169, Development Research Group, World Bank.

Mitchell, Timothy D., Timothy R. Carter, Philip D. Jones, Mike Hulme and Mark New. 2004. A Comprehensive Set of High-Resolution Grids of Monthly Climate for Europe and the Globe. Working Paper \#55, Tyndall Centre for Climate Change Research, Norwich.

Morning, Ann. 2008. Ethnic Classification in Global Perspective: A Cross-National Survey of the 2000 Census Round. Population Research and Policy Review 27:239-272.

Ndegwa, Stephen N. 1997. Citizenship and Ethnicity: An Examination of Two Transition Moments in Kenyan Politics. American Political Science Review 91:599-616.

Nettle, Daniel. 1996. Language Diversity in West Africa. Journal of Anthropological Archaeology $15: 403-438$.

Nichols, Johanna. 1992. Linguistic Diversity in Space and Time. Chicago: University of Chicago Press.

Nugent, Paul. 2008. Putting the History Back in Ethnicity: Enslavement, Religion and Cultural Brokerage in the Construction of Mandika/Jola and Ewe/Agotime Identities in West Africa, c. 1650-1930. Comparative Studies in Society and History 50:920-948.

Nunn, Nathan. 2008. The Long Term Effects of Africa's Slave Trade. Quarterly Journal of Economics 123:139-176.

Partridge, Michael and David Gillard, eds. 1995. British Documents on Foreign Affairs: Reports and Papers from the Foreign Office Confidential Print. Part I: From the Mid-Nineteenth Century to the First World War. Series G: Africa, 1848-1914. (Vol. 19: West Africa: 
Diplomacy of Imperialism, 1868-1895). Frederick, MD: University Publications of America.

Posner, Daniel N. 2003. The Colonial Origins of Ethnic Cleavages: The Case of Linguistic Divisions in Zambia. Comparative Politics 35:127-146.

Posner, Daniel N. 2004a. Measuring Ethnic Fractionalization in Africa. American Journal of Political Science 48:849-863.

Posner, Daniel N. 2004b. The Political Salience of Cultural Difference: Why Chewas and Tumbukas Are Allies in Zambia and Adversaries in Malawi. American Political Science Review 98:529-546.

Poteete, Amy R. 2009. Is Development Path Dependent or Political? A Reinterpretation of MineralDependent Development in Botswana. Journal of Development Studies 45:544-571.

Ranger, Terence. 1983. The Invention of Tradition in Colonial Africa. In The Invention of Tradition, ed. Eric Hobsbawm and Terence Ranger, 211-262. Cambridge: Cambridge University Press.

Robinson, Amanda Lea. 2009. National versus Ethnic Identity in Africa: State, Group and Individual Level Correlates of National Identification. Afrobarometer Working Paper \#112, Michigan State University.

Roeder, Philip. 2001. Ethnolinguistic Fractionalization (ELF) Indices, 1961 and 1985. http://weber.ucsd.edu/ proeder/elf.htm.

Seijas, Tatiana. 2008. The Portuguese Slave Trade to Spanish Manila: 1580-1640. Itinerario 32:1938.

Solway, Jacqueline. 2004. Reaching the Limits of Universal Citizenship: 'Minority' Struggles in Botswana. In Ethnicity and Democracy in Africa, ed. Bruce Berman, Dickson Eyoh and Will Kymlicka, 128-147. Oxford: James Currey.

Sutherland, William J. 2003. Parallel Extinction Risk and Global Distribution of Languages and Species. Nature 423:276-279. 
Taylor, Charles L., and Michael C. Hudson. 1972. World Handbook of Political and Social Indicators. Ann Arbor, MI: ICSPR.

Trouval, Saadia. 1966. Treaties, Borders and the Partition of Africa. Journal of African History 7:279-293.

United Nations. 2008. World Urbanization Prospects: The 2007 Revision. Department of Economic and Social Affairs/Population Division.

United Nations. 2010. World Population Policies 2009. Department of Economic and Social Affairs, United Nations Secretariat.

Vink, Markus. 2003. "The World's Oldest Trade": Dutch Slavery and Slave Trade in the Indian Ocean in the Seventeenth Century. Journal of World History 24:131-177.

Wallerstein, Immanuel. 1960. Ethnicity and National Integration in West Africa. Cahiers d'Études Africaines 1:129-139.

Warren, James Francis. 2007. The Sulu Zone, 1768-1898: The Dynamics of External Trade, Slavery, and Ethnicity in the Transformation of a Southeast Asian Maritime State (2 ed.). Singapore: NUS Press.

Weber, Eugen Joseph. 1976. Peasants into Frenchmen: The Modernization of Rural France, 18701914. Stanford, CA: Stanford University Press.

Webersik, Christian. 2004. Differences that Matter: The Struggle of the Marginalized in Somalia. Africa: Journal of the International African Institute 74:516-533.

Young, M. Crawford. 1976. The Politics of Cultural Pluralism. Madison, WI: University of Wisconsin Press.

Young, M. Crawford. 1994. The African Colonial State in Comparative Perspective. New Haven, CT: Yale University Press.

Yuki, Kazuhiro. 2007. Urbanization, Informal Sector and Development. Journal of Development Economics 84:76-103. 
Table 1: Ethnic Diversity Across Continents

(Source: Alesina et al. (2003))

Sub-Saharan Africa

$\begin{array}{lllll}\text { Obs } & \text { Mean } & \text { Stand Dev } & \text { Min } & \text { Max } \\ 46 & 0.662 & 0.226 & 0 & 0.930 \\ 42 & 0.425 & 0.224 & 0.002 & 0.769 \\ 35 & 0.420 & 0.215 & 0.095 & 0.864 \\ 47 & 0.311 & 0.214 & 0.041 & 0.809\end{array}$

Asia

Americas

Europe 
Table 2: Historical Sources of African Ethnic Diversity

\begin{tabular}{|c|c|c|c|c|c|c|}
\hline \multirow[t]{2}{*}{ Dependent Variable } & Alesina & Alesina & Alesina & Fearon & Fearon & Fearon \\
\hline & (1) & (2) & (3) & (4) & (5) & (6) \\
\hline Ln(Exports/Area) & $\begin{array}{l}0.029 * * * \\
(0.010)\end{array}$ & $\begin{array}{l}0.028 * * \\
(0.013)\end{array}$ & $\begin{array}{l}0.027 * * * \\
(0.010)\end{array}$ & $\begin{array}{l}0.025 * * \\
(0.010)\end{array}$ & $\begin{array}{l}0.028 * * * \\
(0.010)\end{array}$ & $\begin{array}{l}0.024 * * \\
(0.010)\end{array}$ \\
\hline Latitude & $\begin{array}{l}-0.045^{* *} \\
(0.020)\end{array}$ & $\begin{array}{l}-0.041^{*} \\
(0.020)\end{array}$ & $\begin{array}{l}-0.050 * * \\
(0.020)\end{array}$ & $\begin{array}{l}-0.053 * * \\
(0.020)\end{array}$ & $\begin{array}{l}-0.047 * * \\
(0.020)\end{array}$ & $\begin{array}{l}-0.058 * * * \\
(0.021)\end{array}$ \\
\hline $\mathrm{Km} 2$ & $\begin{array}{l}0.044 * * \\
(0.018)\end{array}$ & $\begin{array}{l}0.038^{* *} \\
(0.016)\end{array}$ & $\begin{array}{l}0.047^{*} \\
0.025\end{array}$ & $\begin{array}{l}0.056^{* * * *} \\
(0.018)\end{array}$ & $\begin{array}{l}0.043 * * * \\
(0.014)\end{array}$ & $\begin{array}{l}0.051 * * \\
(0.023)\end{array}$ \\
\hline British Colony & $\begin{array}{l}0.040 \\
(0.075)\end{array}$ & $\begin{array}{l}0.052 \\
(0.071)\end{array}$ & $\begin{array}{l}0.037 \\
(0.076)\end{array}$ & $\begin{array}{l}0.058 \\
(0.077)\end{array}$ & $\begin{array}{l}0.079 \\
(0.077)\end{array}$ & $\begin{array}{l}0.054 \\
(0.073)\end{array}$ \\
\hline French Colony & $\begin{array}{l}0.038 \\
(0.094)\end{array}$ & $\begin{array}{l}0.034 \\
(0.079)\end{array}$ & $\begin{array}{l}0.037 \\
(0.076)\end{array}$ & $\begin{array}{l}0.014 \\
(0.081)\end{array}$ & $\begin{array}{l}0.032 \\
(0.080)\end{array}$ & $\begin{array}{l}-0.002 \\
(0.084)\end{array}$ \\
\hline Portuguese Colony & $\begin{array}{l}0.016 \\
(0.093)\end{array}$ & $\begin{array}{l}0.040 \\
(0.092)\end{array}$ & $\begin{array}{l}0.059 \\
(0.097)\end{array}$ & $\begin{array}{l}0.014 \\
(0.079)\end{array}$ & $\begin{array}{l}0.045 \\
(0.086)\end{array}$ & $\begin{array}{l}0.010 \\
(0.085)\end{array}$ \\
\hline Elevation & $\begin{array}{l}-0.028 \\
(0.035)\end{array}$ & & $\begin{array}{l}-0.029 \\
(0.042)\end{array}$ & $\begin{array}{l}-0.056 \\
(0.018)\end{array}$ & & $\begin{array}{l}-0.061 \\
(0.038)\end{array}$ \\
\hline Temperature & & $\begin{array}{l}0.010 \\
(0.011)\end{array}$ & & & $\begin{array}{l}0.007 \\
(0.010)\end{array}$ & \\
\hline Fractal & & & $\begin{array}{l}-0.324 \\
(1.911)\end{array}$ & & & $\begin{array}{l}-1.154 \\
(1.918)\end{array}$ \\
\hline Constant & $\begin{array}{l}0.244 \\
(0.010)\end{array}$ & $\begin{array}{l}-0.090 \\
(0.205)\end{array}$ & $\begin{array}{l}0.243 \\
(0.451)\end{array}$ & $\begin{array}{l}0.289 \\
(0.260)\end{array}$ & $\begin{array}{l}-0.074 \\
(0.255)\end{array}$ & $\begin{array}{l}0.477 \\
(0.378)\end{array}$ \\
\hline $\mathrm{N}$ & 43 & 43 & 40 & 42 & 42 & 39 \\
\hline $\mathrm{R}^{2}$ & 0.563 & 0.570 & 0.578 & 0.604 & 0.589 & 0.619 \\
\hline
\end{tabular}

$* \mathrm{p} \leq 0.1, * * \mathrm{p} \leq 0.05 ; * * * \mathrm{p} \leq 0.01$ (two-tailed); robust standard errors in parentheses. 
Table 3: African and Global Ethnic Diversity

\begin{tabular}{|c|c|c|c|c|}
\hline \multirow[t]{2}{*}{ Dependent Variable } & Alesina & Alesina & Fearon & Fearon \\
\hline & (1) & (2) & (3) & (4) \\
\hline \multirow[t]{2}{*}{ Elevation } & 0.003 & 0.026 & 0.012 & $0.034 *$ \\
\hline & $(0.018)$ & $(0.016)$ & $(0.020)$ & $(0.017)$ \\
\hline \multirow[t]{2}{*}{ Latitude } & $-0.067 * * *$ & $-0.053 * * *$ & $-0.071 * * *$ & $-0.056 * * *$ \\
\hline & $(0.020)$ & $(0.018)$ & $(0.022)$ & $(0.021)$ \\
\hline \multirow[t]{2}{*}{ British Colony } & 0.002 & 0.023 & 0.023 & 0.046 \\
\hline & $(0.051)$ & $(0.048)$ & $(0.056)$ & $(0.053)$ \\
\hline \multirow[t]{2}{*}{ French Colony } & -0.020 & -0.022 & -0.036 & -0.032 \\
\hline & $(0.059)$ & $(0.053)$ & $(0.058)$ & $(0.053)$ \\
\hline \multirow[t]{2}{*}{ Spanish Colony } & -0.083 & -0.041 & -0.094 & -0.056 \\
\hline & $(0.058)$ & $(0.059)$ & $(0.059)$ & $(0.063)$ \\
\hline \multirow[t]{2}{*}{$\mathrm{Km}^{2}$} & 0.012 & -0.004 & 0.021 & 0.008 \\
\hline & $(0.012)$ & $(0.012)$ & $(0.013)$ & $(0.013)$ \\
\hline \multirow[t]{2}{*}{ Europe Dummy } & $-0.105 * *$ & $-0.123 * *$ & -0.078 & $-0.096^{*}$ \\
\hline & $(0.053)$ & $(0.049)$ & $(0.056)$ & $(0.054)$ \\
\hline \multirow[t]{2}{*}{ SSAfrica Dummy } & $0.177 * * *$ & 0.033 & $0.200 * * *$ & 0.071 \\
\hline & $(0.048)$ & $(0.058)$ & $(0.050)$ & $(0.060)$ \\
\hline \multirow[t]{2}{*}{ Ln(Exports/Area) } & & $0.029 * * *$ & & $0.025 * * *$ \\
\hline & & $(0.006)$ & & $(0.006)$ \\
\hline \multirow[t]{2}{*}{ Constant } & 0.498 & 0.520 & 0.330 & 0.337 \\
\hline & $(0.175)$ & $(0.166)$ & $(0.202)$ & $(0.187)$ \\
\hline $\mathrm{N}$ & 157 & 157 & 148 & 148 \\
\hline $\mathrm{R}^{2}$ & 0.389 & 0.472 & 0.424 & 0.486 \\
\hline
\end{tabular}

$* \mathrm{p} \leq 0.1, * * \mathrm{p} \leq 0.05 ; * * * \mathrm{p} \leq 0.01$ (two-tailed); robust standard errors in parentheses. 
Table 4: Percent Urban by Area

(Source: United Nations (2008))

$\begin{array}{lllll}\text { Region } & \mathbf{1 9 5 0} & \mathbf{1 9 7 5} & \mathbf{2 0 0 0} & \mathbf{2 0 3 0} \text { (projected) } \\ \text { Sub-Saharan Africa } & 11.1 & 21.7 & 32.8 & 48.2 \\ \text { Asia } & 16.8 & 24.0 & 37.1 & 54.1 \\ \text { Latin America and Caribbean } & 42.0 & 61.2 & 75.4 & 84.3 \\ \text { Europe } & 50.5 & 65.6 & 71.7 & 78.3 \\ \text { Oceania } & 62.0 & 71.5 & 70.5 & 73.8 \\ \text { North America } & 63.9 & 73.8 & 79.1 & 86.7\end{array}$


Table 5: Changes in Ethnic Identity, 1961-1985

(Dependent Variable: Change in Roeder (2001), 1961-1985)
(1)
(2)
(3)
(4)

Urbanization 1950-1975

$\begin{array}{llll}-0.838 * * & -0.958 * * & -0.834 * * & -1.149 * * * \\ (0.381) & (0.361) & (0.405) & (0.379) \\ 0.024 & -0.0001 & 0.027 & 0.012 \\ (0.189) & (0.053) & (0.017) & (0.030) \\ & 0.222 & & \\ & (0.497) & & \\ & 0.003 & & \\ & (0.002) & & \end{array}$

Fertility 1960-1985

0.233

(0.548)

Net Migration 1960-1985

$-0.118^{* * *}$

$(0.027)$

0.552

Mortality 1960-1985

$(0.929)$

Illiteracy 1950-1975

0.622

(0.891)

Agricultural Productivity 1961-1985

Constant

$$
\begin{aligned}
& 0.004 \\
& (0.018)
\end{aligned}
$$$$
0.033
$$$$
0.012
$$$$
\text { (0.550) }
$$

(0.057)

(0.021)

0.019

45

18

45

28

$\mathrm{R}^{2}$

0.208

0.347

0.273

0.404

$* \mathrm{p} \leq 0.1, * * \mathrm{p} \leq 0.05 ; * * * \mathrm{p} \leq 0.01$ (two-tailed); robust standard errors in parentheses. 


\section{Appendix 1: Data Sources}

\section{$\underline{\text { Dependent Variables }}$}

Alesina: ELF as measured by Alesina et al. (2003).

Fearon: ELF as measured by Fearon (2003).

Roeder: Change in ELF between 1961 and 1985 as measured by Roeder (2001).

$\underline{\text { Independent Variables }}$

Agricultural Productivity: Annual growth rate in net agricultural production per capita per country, 1961-1985. Source: FAO.

Area: Natural $\log$ of a country's area in square kilometers. Source: Center of International Development, Harvard University.

British Colony: Dummy equals 1 if a state was ever colonized by the UK and 0 otherwise.

Elevation: Natural log of a country's mean latitude. Source: Center of International Development, Harvard University.

Fractal: Natural log of a measure computing the degree by which a given country's non-coastal borders are straight lines, with the measure decreasing as the border approaches a straight line. Source: Alesina et al. (2011).

French Colony: Dummy equals 1 if a state was ever colonized by France and 0 otherwise.

GDP/c Growth: GDP/capita growth per country. Source: Heston, Summers, and Aten (2009).

Latitude: Natural log of a country's absolute central latitude. Source: Center of International Development, Harvard University.

Net Migration: Average annual rate of net migration per country. Source: United Nations Population Division, World Population Prospects.

Polity IV: Net change over time in a country's Polity IV rating. Source: Polity IV.

Portuguese Colony: Dummy equals 1 if a state was initially colonized by Portugal and 0 otherwise.

Spanish Colony: Dummy equals 1 if a state was initially colonized by Spain and 0 otherwise.

Slave Exports: Natural log of the total number of slaves exported from a given state between 1400 and 1900, divided by the area of the state and multiplied by 1000. Source: Nunn (2008).

Temperature: The natural log of the average mean temperature per country, 1961-1990. Source: Mitchell, Carter, Jones, Hulme, and New (2004).

Urbanization: Average annual growth rate in the percentage of residents living in cities. Source: United Nations (2008). 


\section{Appendix 2: Estimates of Slave Exports Outside Africa}

$\begin{array}{llll}\text { Region } & \text { Slave Exports } & \text { Ln(Exports/Area) } & \text { Source } \\ \text { Afghanistan } & 150,000 ? & 5.445 & \text { Levi }(2002,284) \\ \text { Iran } & 350,000 & 5.358 & \text { Hopkins }(2008,645) \\ \text { South-East Asia } & 300,000 & & \text { Seijas }(2008,23) \\ & & & \text { Warren }(2007, \mathrm{xxxv}) \\ \text { Indonesia } & & 4.820 & \\ \text { Malaysia } & & 4.820 & \\ \text { Philipppines } & & 4.820 & \text { Kizilov }(2007,7) \\ & & & \\ \text { Eastern Europe/Russia } & 2,000,000 & 4.684 & \\ \text { Belarus } & & 4.684 & \\ \text { Estonia } & & 4.684 & \\ \text { Georgia } & & 4.684 & \\ \text { Latvia } & & 4.684 & \\ \text { Lithuania } & & 4.684 & \text { Vink }(2003,141) \\ \text { Moldova } & & 4.684 & \end{array}$

